\title{
DISEMINATION MODEL OF HEALTH INFORMATION FOR RURAL POOR CITIZEN IN DONGKO TRENGGALEK
}

\author{
Diah Handayani \\ Institut Agama Islam Negeri Kediri, Indonesia \\ diahhandayani.kpi@iainkediri.ac.id
}

\begin{abstract}
This study aims to describe the dissemination model developed in Dongko District, Trenggalek Regency. This study uses a dissemination model approach by $\mathrm{S}$. Notoadmodjo which divides the elements of communication into four parts, namely health communicators, media messages, effects and communication context. The data collection process was obtained from observations in rural areas in Dongko Village in Trenggalek Regency. Interviews were conducted with several health personnel such as village midwives, village nurses, posyandu volunteers and PMD (Village Community Empowerment) officers. The results showed that health dissemination for the rural poor in Dongko District was limited to the dissemination of health information and the distribution of health assistance for the rural poor. The role of education through literacy in health media in rural areas is dominated by the role of village leadership and the lack of public awareness of changing their health behavior. This is because changes in behavior through daily communication to educate the public have not been carried out optimally either through personal communication or group communication in rural areas.
\end{abstract}

Keywords : Disemination Model, Health Communication, Rural.

ACCEPTED : January $2^{\text {nd }}, 2021$ REVIEWED: January $13^{\text {th }}, 2021$ PUBLISHED: February $12^{\text {th }}, 2021$

\section{Introduction}

Currently, health information is available in various sources, namely magazines, radio, newspapers, television, libraries, the internet, and so on. This information has an important role for society to obtain 
better achievements in various fields of life, such as work, education and health. For this reason, efforts to become a member of society who are literate (literate) with health information are the right of every citizen as stated in Health Law No. 36 of 2009, article 6 that: 1) Everyone has the right to receive information in education about balanced and responsible health. 2) Also strengthened by the Government of the Republic of Indonesia Regulation No. 46 of 2014 concerning the Health Information System which states; 3) Health information is health data that has been processed or processed into a form that contains value and meaning which is useful for increasing knowledge in supporting health development; 4) One of the determinants of regional conditions is the Human Development Index (HDI) in terms of the level of public health which also represents the level of community welfare in an area; 5) The Human Health Index in the health sector of Trenggalek Regency was 68.71 in 2018 under the HDI of East Java of 70.77 points; 6) Based on this, this study focuses on health information dissemination activities carried out in rural areas of Dongko District, Trenggalek Regency.

Table 1. Human Development Index (HDI) of East Java Province

\begin{tabular}{llllll}
\hline Territory & 2014th & 2015th & 2016th & 2017th & 2018th \\
\hline Jawa Timur & 68.14 & 68.95 & 69.74 & 70.27 & 70.77 \\
Blitar & 66.88 & 68.13 & 68.88 & 69.33 & 69.93 \\
Kediri & 68.44 & 68.91 & 69.87 & 70.47 & 71.07 \\
Malang & 65.59 & 66.63 & 67.51 & 68.47 & 69.4 \\
Lumajang & 62.33 & 63.02 & 63.74 & 64.23 & 64.83 \\
Jember & 62.64 & 63.04 & 64.01 & 64.96 & 65.96 \\
Banyuwangi & 67.31 & 68.08 & 69 & 69.64 & 70.06 \\
Bondowoso & 63.43 & 63.95 & 64.52 & 64.75 & 65.27 \\
Situbondo & 63.91 & 64.53 & 65.08 & 65.68 & 66.42 \\
Probolinggo & 63.04 & 63.83 & 64.12 & 64.28 & 64.85 \\
Pasuruan & 64.35 & 65.04 & 65.71 & 66.69 & 67.41 \\
Sidoarjo & 76.78 & 77.43 & 78.17 & 78.7 & 79.5 \\
Mojokerto & 70.22 & 70.85 & 71.38 & 72.36 & 72.64 \\
Jombang & 69.07 & 69.59 & 70.03 & 70.88 & 71.86 \\
Nganjuk & 69.59 & 69.9 & 70.5 & 70.69 & 71.23 \\
Madiun & 68.6 & 69.39 & 69.67 & 70.27 & 71.01
\end{tabular}




\begin{tabular}{llllll} 
Magetan & 70.29 & 71.39 & 71.94 & 72.6 & 72.91 \\
Ngawi & 67.78 & 68.32 & 68.96 & 69.27 & 69.91 \\
Bojonegoroo & 65.27 & 66.17 & 66.73 & 67.28 & 67.85 \\
Tuban & 64.58 & 65.52 & 66.19 & 66.77 & 67.43 \\
Lamongan & 69.42 & 69.84 & 70.34 & 71.11 & 71.97 \\
Gresik & 72.84 & 73.57 & 74.46 & 74.84 & 75.28 \\
Bangkalan & 60.71 & 61.49 & 62.06 & 62.3 & 62.87 \\
Sampan & 56.98 & 58.18 & 59.09 & 59.9 & 61 \\
Pamekasan & 62.66 & 63.1 & 63.98 & 64.93 & 65.41 \\
Sumenep & 61.43 & 62.38 & 63.42 & 64.28 & 65.25 \\
Kota Kediri & 74.62 & 75.67 & 76.33 & 77.13 & 77.58 \\
Kota Blitar & 75.26 & 76 & 76.71 & 77.1 & 77.58 \\
Kota Malang & 78.96 & 80.05 & 80.46 & 80.65 & 80.89 \\
Kota & 70.49 & 71.01 & 71.5 & 72.09 & 72.53 \\
Probolinggo & & & & & \\
Kota & 73.23 & 73.78 & 74.11 & 74.39 & 74.78 \\
Pasuruan & & & & & \\
Kota & 75.04 & 75.54 & 76.38 & 76.77 & 77.14 \\
Mojokerto & & & & & \\
Kota & 78.81 & 79.48 & 80.01 & 80.13 & 80.33 \\
Madiun & & & & & \\
Kota & 78.87 & 79.47 & 80.38 & 81.07 & 81.74 \\
Surabaya & & & & & \\
Kota batu & 71.89 & 72.62 & 73.57 & 74.26 & 75.04 \\
\hline Source: & & & & \\
\hline
\end{tabular}

Source : ipm.bps.go.id

Trenggalek Regency, which is in the middle position in the achievement of HDI figures in East Java, makes this a separate thought for the local government. The Human Development Index shown is related to the number of basic needs, one of which is the basic health needs for rural communities. Basic health services in rural areas lead to several important roles that local governments must play to increase the leverage of development in their regions.

Several references to previous research on the problem of community powerlessness in identifying health problems are influenced by factors related to people's ability to identify health problems such as 
health level, knowledge, awareness, concern, habits, leadership, social capital, access to health information, and the role of health facilitator. This empowerment process based on this research is linked to the community empowerment process including the process of empowering and utilizing resources within the community as well as the process of facilitating and supporting resources from outside the community (Sutisna Sulaeman, 2012) .

Furthermore, Saleha Rodiah's research, in her research results, states that communicators in health dissemination involve various parties with a tiered empowerment system whose main subject is the community. The empowering agent as a communicator of information dissemination plays a role as a facilitator, motivator and mediator. The message management strategy he uses is health education and promotion towards health-minded behavior change. Information is conveyed through outreach aimed at village and community officials. Persuasive information is actively carried out so that people can improve the quality of their health (Nutbean, 2006).

The difference in previous research is that this study examines the dissemination (dissemination) of health information in terms of health communication theory, which includes elements of health communicators, communication, media messages, effects and health communication context (Liliweri, 2013). Furthermore, related to information dissemination as a form and process of communication. Hamad said that the discussion of information dissemination uses $5 \mathrm{~W}$ and $1 \mathrm{H}$. At least, the elements of communicators (who), messages (what), and audiences (whom) are important research variables to be considered in information dissemination studies. For this reason, this study has 3 (three) research objectives, namely knowing the role of communicators, message management and audiences in the dissemination of information on rural community health in Dongko District, Trenggalek Regency. In addition, the results of an interview with the Head of Village Community Empowerment (PMD), Dongko District, Trenggalek Regency stated that "for the Dongko community, the level of community participation in participating in posyandu activities is very good, but is still limited to the problem of equitable health development". 
This shows the need for efforts to optimize the role of society in health development. Where the Dongko District, Trenggalek Regency, has the Dongko Health Center and the Pandean Community Health Center. The Puskesmas Dongko oversees the villages of Dongko, Pringapus, Sumber Bening, Pandean and Watu Agung (coverage in this study).

The activity of disseminating health information as an important part of accelerating the achievement of health development goals as a study in information and communication science, a successful information dissemination or dissemination process will be able to have an effect in all fields For this reason, information dissemination needs to be supported by the use of appropriate communication elements in improving the quality of public health and achieving complete health in accordance with the mandate of the Law in Article 1 that: "Health is a state of health, both physically, mentally, spiritually and socially, which enables everyone to live productively socially and economically".

Basically health communication is inherent in the conceptual relationship between "communication" and "health" so that the concept of communication gives a role to the words that follow it. Elayne Clift and Vicki Freimuth said that health communication is health education, which is an approach that emphasizes efforts to change the health behavior of the audience (macro scale) so that they have sensitivity to certain health problems that have been defined at a certain time (Liliweri, 2013: 47).

Health communication is the process of educating individuals or the public in order to solve the health problems they face. The purpose of health education is to teach individuals, groups or communities to be able to foster healthy behavior. Health education according to a structural functional perspective serves to keep people from adopting healthy living habits. If people are able to maintain their own health, it will affect other aspects of life which in turn will create a social order.

In the context of health communication, there are several agents as well as health communicators including village midwives, village nurses, health cadres, officers and village assistants. Peer educators as the main actors in health education have a central function. Peer educators are in charge of providing information and counseling services on public health to their peers. Through the role of peer educators, it is hoped that 
peers can change their behavior by practicing healthy living and avoiding the risk of disease. Apart from educational and counseling activities, peer educators also play a role in designing and carrying out supporting activities, such as religion, sports, arts, and soft skills (leadership and entrepreneurship). This activity is not only intended for peer educator groups, but also for peers.

The Puskesmas and health assistants or cadres function as facilitators for the sustainability of activities designed by peer educators. The Health Office facilitates the provision of a budget and provides social security. The health worker is in charge of providing guidance, direction and advice so that all activities that have been designed can be carried out properly and achieve the desired goals. Meanwhile, health officers at the sub-district level are tasked with monitoring and evaluating the implementation of health programs at the sub-district level. In addition, health promotion has the task of disseminating information on supporting activities and policies that have been outlined by the Health Office and the government. All of these actors carry out their respective duties and functions and work with each other for the realization of the goals of the health program.

Communication is a process that contains ideas, ideas and information that will be conveyed by the messenger (communicator) to the message recipient (communicant). The information conveyed by the communicator is expected to be interpreted well by the communicant so that both have the same ideas, ideas, and information (Cangara, 1998: 17). Meanwhile, Rogers (quoted by Sutarto, 1992: 8) states that communication can also be understood as a process of transferring information that aims to change the behavior of the communicant as desired. Therefore, the communication process that takes place as an effort to inform the program from program makers to program implementers and target groups does not only take place in the domain of common understanding between them, but more than that, it must create changes in the behavior of program implementation and program target groups. In essence, humans are creatures who are weak and helpless, but thus they already have an innate latent potential. which requires communication to other humans (Subqi, 2016:165). 
An equally important factor in the communication process as an effort to support program effectiveness is the form or nature of communication, both formal and informal. In connection with the flow of communication, the communication process can take place through one-way or two-way (reciprocal) flow. One-way communication flow is considered more efficient, but less effective because the communicant does not get an explanation or confirms if there is still unclear information. Conversely, the two-way communication flow will be considered more effective because the communicator will get feedback, while the communicant will get a more detailed explanation of the information he receives.

According to Alo Liliweri (2013: 48) in overcoming health problems, several important elements are needed, including: communication interaction, equality in communication, which reflects the equality between health communicators, communicants, media messages, effects and communication context. health. There is also operation at the level or context of communication between individuals, groups, organizations, the public, and mass communication.

Meanwhile, dissemination is an activity aimed at target groups or individuals so that they can obtain information, raise awareness, receive and ultimately utilize the information. Dissemination is an act of innovation that is compiled and disseminated based on a careful planning with a foresight either through discussions or other forums that are deliberately programmed so that there is an agreement to implement the innovation. Information is data that has been processed for a specific purpose. The purpose is to produce a decision (Meliono, 1990: 331). Reference information is facts that have been processed into useful data and can be used by anyone who needs these data.

In other words, dissemination is an activity of disseminating information to the community. Its activities can be carried out through training or workshops, seminars and communications. Apart from various training activities, information dissemination can be held in the form of press conferences, press interviews, article writing, publication or through publishing.

\section{Research Methods}


This study uses a qualitative research method with a case study approach. Qualitative research is research that intends to understand the phenomena experienced by research subjects such as behavior, perception, motivation, action and others. The research location was conducted in Dongko District, Trenggalek Regency, East Java. The selection of qualitative methods with a case study approach is suitable for researching the model of dissemination of basic health services for the poor in Dongko District, Trenggalek Regency. The qualitative approach uses human analysis as a research instrument. Using inductive analysis, directs research objectives in an effort to obtain a basic theory, is descriptive in nature and prioritizes process over results. According to Yin, the case study approach is a suitable strategy when the subject matter of a research is related to how and why and the researcher has little chance to be able to control the events to be studied and the focus of his research on current phenomena (Yin, 2008).

The cases studied in this study are cases that use community empowerment. Dissemination is one of the efforts seen in increasing empowerment of the community. So that health dissemination is considered effective to be accessed by rural communities at large in order to overcome health problems.

The data collection technique uses participatory observation, namely using direct observation techniques in the field and literature study. Unstructured interviews, focus group discussions (FGD), related to communicator messages, audiences and message management. While the research subjects were seven sources, selected purposively who were directly involved in the dissemination of health information through community empowerment. Consists of: the head of the Village Community Empowerment (PMD) section of Dongko District, the Health Promoter of the Dongko Health Center, the Head of the Dongko Village Welfare, the Head of the PKK Driving Team, Village Midwives, village nurses, and health cadres. Data analysis was carried out interactively and directly and data analysis was carried out, namely: data reduction, data presentation, and drawing conclusions and verification. 


\section{Results And Discussion}

Dongko is a village in Dongko District, Treggalek District. Dongko Village is one of 152 villages in the Trenggalek Regency area. The condition of the Dongko Village area is mountainous. Has a height of 582 meters above sea level. The area of the village reaches 15,109,040 $\mathrm{m} 2$ of that area. Dongko Village has 7 hamlets, $14 \mathrm{RW}$ and $71 \mathrm{RT}$.

Until now, public health programs in Dongko Village have been running well, although it is acknowledged by several parties that there are limitations in facilities and infrastructure and institutional strengthening. This achievement is the result of ongoing multi-stakeholder cooperation, including the motivation of the Trenggalek District Health Office, the Dongko Health Center and implementation at the village level, namely village midwives and health cadres. There are several coaching and training activities carried out by the Dongko Health Center as the person in charge of the activity program in the Dongko Village area to health cadres as a health program to increase its acceleration. As said by Mrs. Rina Kuswarningsih, the health promoter of Dongko District, she stated: "In Dongko Village, which is included in Dongko District, it has achieved free ODF. This indicator indicates that the risk of sanitation in Trenggalek Regency in 2013-2014 is categorized as low. However, in 2015 it entered free ODF which made Dongko Village enter the moderate category. This measurement measures sanitation and SKPD and ERHA data".

Other activities that have caused this category to be moderate are that it has been implemented in Dongko Village in the last two years by increasing the role of cadres in socialization through basic health service programs, environmental health, posyandu activities and RW-level healthy gymnastics activities. Even today, ODGJ (People With Mental Disorders) exercise activities are also being developed. This makes the activity stimuli have a high quality of service, so the cadres, with the guidance of the Dongko Health Center, include some of their program activities to take part in competitions both at district and national levels. In fact, one of the health promoters of Dongko District has won the Best National Health Promoter in 2019. The enthusiasm of health promoters and health cadres is continuously maintained.

The village health program is implemented under the guidance of the Puskesmas Dongko (Public health center of Dongko) which assigns 
several medical personnel to supervise, monitor and provide guidance so that the program runs. The health cadres in collaboration with village midwives are scattered in each RT and RW. The form of service is dominated by monitoring and handling maternal and child health problems. This can be seen from table 2. The provision of basic services for the need for clean water and ORS are the basic services included, because Dongko Village is in the middle category of sanitation assessment that is prone to diarrhea disease. Therefore, the development of community empowerment and participation in the environmental health sector is given top priority.

Table 2. Activities Program Activities

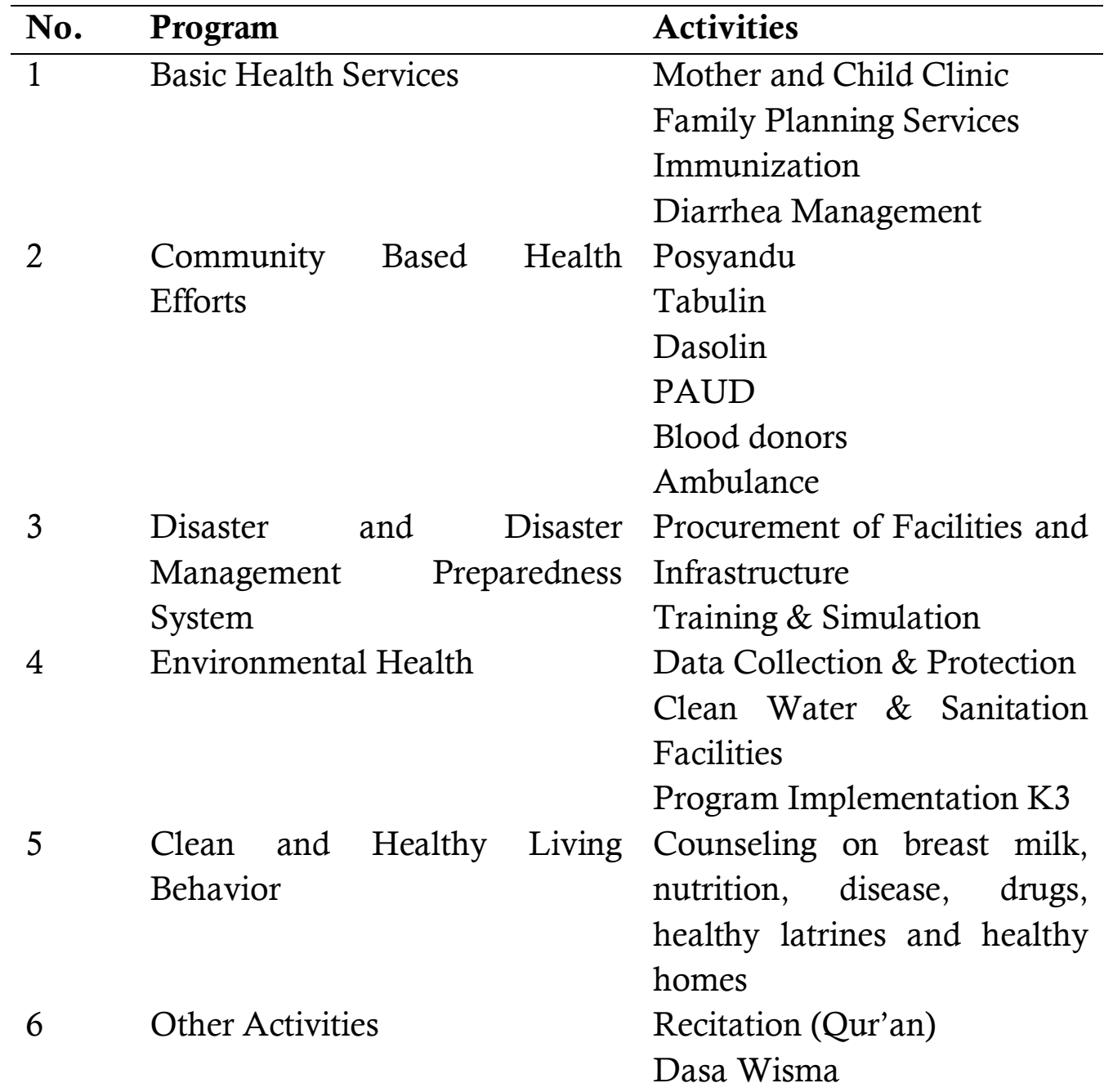


Source : Dokumen Puskesmas Dongko, 2018.

Table 3. Basic Health Services

\begin{tabular}{llll}
\hline No & Activities & Description & Activities \\
& & \\
\hline 1 & Mother and Child & Services for pregnant \\
Clinic & women, childbirth, \\
2 & Family Planning & Active / passive & $1442 / 115$ \\
& participants & \\
& Services & Implant/IUD & $65 / 58$ \\
& & MOW/MOP & $22 / 14$ \\
3 & Immunization & BSG/Polio & $12 / 8$ \\
& & Measles /TT & $11 / 7$ \\
& & Hipatitis AB/C & $7 / 6 / 10$ \\
4 & Handling diarrhea & ORS administration \\
\hline
\end{tabular}

Community empowerment efforts through health programs that raise public awareness so that a healthy lifestyle does not contract diarrhea. This is to strengthen community participation in the environmental health sector to get top priority.

Table 4. Community Based Health Efforts in Dongko

\begin{tabular}{llll}
\hline No & Facilities & / Amount & Evidence \\
& Activities & & \\
\hline 1 & Posyandu Pratama & 4 & \\
2 & Posyandu Madya & 12 & 3 posyandu \\
& & & menuju \\
3 & Posyandu Mandiri & 2 & \\
4 & Posyandu & & \\
& participants are \\
& active / passive \\
& $201 / 16$ children \\
\hline
\end{tabular}




\begin{tabular}{|c|c|c|c|c|}
\hline 5 & Tabulin & & $15 \mathrm{RW}$ & \\
\hline 6 & Dasolin & & $17 \mathrm{RW}$ & \\
\hline 7 & PAUD & & 3 & \\
\hline 8 & $\begin{array}{l}\text { Blood } \\
\text { participants }\end{array}$ & donation & 120 orang & 69 aktif \\
\hline 9 & $\begin{array}{l}\text { Family } \\
\text { Park }\end{array}$ & Medicine & $1819 \mathrm{KK}$ & \\
\hline 10 & Ambulance & & 1 & \\
\hline
\end{tabular}

Table 5. Environmental Health

\begin{tabular}{|c|c|c|c|}
\hline No & Activities & Description & Evidence \\
\hline 1 & $\begin{array}{ll}\text { Clean } & \text { Water } \\
\text { Facilities } & \end{array}$ & 6 & \\
\hline 2 & Dug well & 93 & \\
\hline 3 & $\begin{array}{l}\text { Customer } \\
\text { PDAM }\end{array}$ & 0 & \\
\hline 4 & Water pipe & $102 \mathrm{KK}$ & \\
\hline 5 & $\begin{array}{l}\text { Shallow Septic } \\
\text { Tank }\end{array}$ & 0 & \\
\hline 6 & $\begin{array}{l}\text { Electric Water } \\
\text { Pump }\end{array}$ & $57 \mathrm{KK}$ & \\
\hline 7 & $\begin{array}{l}\text { The use of } \\
\text { springs for RT }\end{array}$ & $1683 \mathrm{KK}$ & $\begin{array}{l}\text { Along with } \\
\text { protection program }\end{array}$ \\
\hline 8 & $\begin{array}{l}\text { Use of springs for } \\
\text { mosques }\end{array}$ & 14 & \\
\hline 9 & $\begin{array}{l}\text { Use of springs for } \\
\text { schools }\end{array}$ & 2 & \\
\hline 10 & $\begin{array}{l}\text { Use of springs for } \\
\text { swimming pools }\end{array}$ & 1 & \\
\hline 11 & $\begin{array}{l}\text { Use springs for } \\
\text { refilling }\end{array}$ & 14 & \\
\hline 12 & $\begin{array}{l}\text { Use of springs for } \\
\text { restaurants }\end{array}$ & 10 & \\
\hline
\end{tabular}


13 Jumatik activities Once a week

14 Temporary waste 3

management

UKBM is an activity program that fosters public awareness so that a healthy lifestyle is part of their daily activities. This is indicated by the awareness of mothers to routinely enroll their children in posyandu services, participate in blood donation programs and awareness of having family medicinal plants (TOGA). Data on community-based health efforts in Dongko Village community-based health efforts in Dongko Village are shown in table 4.Environmental health programs include various activities that support ecological balance, namely harmony between humans and their environment in order to achieve the quality of human life and the environment in order to achieve a quality human life. healthy and happy. This program of activities includes the following: sanitizing clean water sources, sanitizing housing environments such as sanitation facilities and waste water disposal, sanitizing places for managing food to monitoring mosquito larvae and eradicating mosquito nests (PSN). In addition, this program also includes providing consultations on sanitation and diseases related to the environment in Dongko Village. Most of the environmental health programs are being and have been implemented, as shown in table 5. Clean and healthy living behavior is the basic capital for efforts to build quality human resources.

Table 6. Clean and Healthy Behavior Activities

\begin{tabular}{clll}
\hline No & \multicolumn{1}{c}{ Activities } & \multicolumn{1}{c}{ Amount } & Evidence \\
\hline 1 & $\begin{array}{l}\text { Exclusive } \\
\text { breastfeeding } \\
\text { counseling }\end{array}$ & 1820 moms & \\
2 & $\begin{array}{l}\text { Healthy / unhealthy } \\
\text { family status }\end{array}$ & Pilot latrine \\
3 & $\begin{array}{l}\text { Penyuluhan jamban once } \\
\text { sehat }\end{array}$ & \\
4 & $\begin{array}{l}\text { Nutrition education once } \\
\text { Smoking prohibition } \\
\text { education }\end{array}$ & \\
\hline
\end{tabular}




\begin{tabular}{|c|c|c|c|}
\hline 6 & $\begin{array}{l}\text { TB / DHF / AIDS } \\
\text { / HIV counseling }\end{array}$ & Once & \\
\hline 7 & $\begin{array}{l}\text { Extension of Drugs } \\
\text { / Bird Flu }\end{array}$ & once & \\
\hline 8 & Disaster Education & Once & \\
\hline 9 & $\begin{array}{ll}\text { Dasa } & \text { Wisma } \\
\text { counseling } & \end{array}$ & once & $\begin{array}{l}\text { Supporting } \\
\text { activities }\end{array}$ \\
\hline 10 & Recitation (Qur'an) & $\begin{array}{l}15 \text { activities per } \\
\text { month for all } \\
\text { RWs }\end{array}$ & $\begin{array}{l}\text { Supporting } \\
\text { activities }\end{array}$ \\
\hline 11 & $\begin{array}{l}\text { Healthy Gymnastics } \\
\& \text { people with } \\
\text { mental disorders }\end{array}$ & $\begin{array}{l}2 \text { times per } \\
\text { month in several } \\
\text { RWs }\end{array}$ & $\begin{array}{l}\text { Supporting } \\
\text { activities }\end{array}$ \\
\hline
\end{tabular}

Dissemination of information, in this case related to health information in the community empowerment subsystem, is the form and method of organizing health efforts, at the individual, group level as well as the wider community that is planned, integrated and sustainable. Community empowerment efforts are carried out to achieve maximum public health degrees. This is in accordance with the Ministry of Health's Instruction and regional health officials. This makes communicators (source) seek to develop health promotion programs in increasing health degrees.

The goal of community empowerment in Dongko Village is to increase the community's ability to have a healthy lifestyle, be able to independently solve health problems, play an active role in every health development, and can become a driving force for health-minded village development.

Health workers, village heads and village midwives are activists and communicators (empowerment agents) of health empowerment in delivering various health information to the community in Dongko Village. This information is obtained from the central and local governments as a source of health information.

The Ministry of Health, through health promotion efforts, states that empowerment in the community is carried out in stages. The stages of the empowerment process are generally held using an approach called 
community organization / community development. Starting from health workers as health promoters of health centers who develop cooperation and empower community leaders. Community organizing can be applied in a manner, such as RT / RW, schools and Islamic boarding schools.

The results of the FGD of this study with residents of Dongko Village obtained information that the agents for empowering health workers were recognized by the community as having the competence and credibility in conveying their ideas and motivating them to obtain information. In this case, the health sector is useful for improving their quality of life. In addition, the healthy behavior of community and religious leaders is a reference for the community and religious leaders as a reference for the surrounding community.

Enabling agencies involve various parties with authority in the process of disseminating health information. This broad community involvement is so that health information is more accurate and effective with the wider public. According to one of the targets of health promotion is the tertiary group (Tertiery Target), which are policy makers at the central and regional levels who will influence the behavior of community leaders (Head of RT / RW and their secretaries) and religious leaders (ustadz, MUI) and the general public (Notoatmodjo, 2007).

This effort is in line with advocacy as a health promotion strategy. Rodiah, Rosfiantika \& Yanto stated that in terms of communication science, advocacy is seen as a form of interpersonal and mass communication aimed at decision makers. (Rodiah, Rosfiantika \& Yanto, 2011).

Empowerment involvement by community leaders is guided by health workers to empower PKK cadres through the determination of Community-Based Health Efforts (UKBM) which are generally formed and suitable to solve problems that occur in the field. These efforts include the Health Fund, Maternity Savings (Tabulin), Village Maternity Cottage (Polindes), Village Ambulance, and Village Health Post (Poskedes).

For example, the Village Health Post (Poskedes), the material provided includes, among other things, observation, how to handle risks, 
and how to deal with emergencies. Apart from that, he also delivered community empowerment efforts, especially individual counseling techniques and family counseling or family counseling. As mentioned by the head of the PKK Village PKK activist team, the involvement of the authorized parties was carried out through mini workshops (lokmin) which were held in each RW every month which was attended by PKK cadres and posyandu cadres. "So far, Puskesmas Dongko has tried to do empowerment through lokmin (mini workshops) even though the participants / cadres are still those people."

Cadres are trained to carry out services for UKBM activities (for example Poskedes). Cadres will do more community empowerment by becoming facilitators in activities related to the process of solving problems currently being faced by individuals, families, or groups. So that the cadres will do a lot of family counseling activities (at Poskedes), family counseling (through home visits), group counseling (Dasa Wisma). As Irianto mentioned, mobilizing human resources is encouraged to give whatever they have to solve problems faced by society (Irianto, 2014).

Meanwhile, the relationship with the media. Providing health information is carried out through lectures and recitation activities for mothers and fathers which are held once a week with a different schedule. This aspect is usually related to the behavior of the community members who are fostered by cadres so that a Clean and Healthy Lifestyle (PHBS) is created. It turns out that based on field observations in Dongko, there are 4 mosques and Islamic boarding schools scattered in the local RT-RT.

In the final stage of the community empowerment process in the health sector as a sustainable cycle (sustainability), the puskesmas and community leaders carry out Support, Monitoring and Guidance activities (DPB). In this step, the puskesmas (assisted by the Trenggalek District Health Office) implements a health promotion strategy, namely building an atmosphere and advocacy.

According to Notoadmodjo, the community is gradually empowering in the field of information activities, namely as a liaison (facilitator) to provide information related to posyandu schedules and others. Related to the role of the communicator, which states that the expertise of communicators in conveying messages about a disease can 
increase public knowledge and foster trust in communicators (counselors) and a willingness to stay away from risky disease behaviors such as drugs and free sex (Niftah \& Rahmat, 2017). Providing learning about health to accompany the goals of community empowerment in the health sector are 1) growing awareness, knowledge, understanding of health for individuals, groups and improving health through daily learning processes that begin with obtaining health information; 2) the emergence of will or will as a continuation of awareness and understanding of health, sometimes referred to as attitude. The factors that support the continuation of the will, are the facilities and infrastructure that support the action; 3) the emergence of community capacity in the field of health, which means that the community individually as well as in groups has been able to manifest a will in the form of healthy behaviour (Notoatmodjo, 2007).

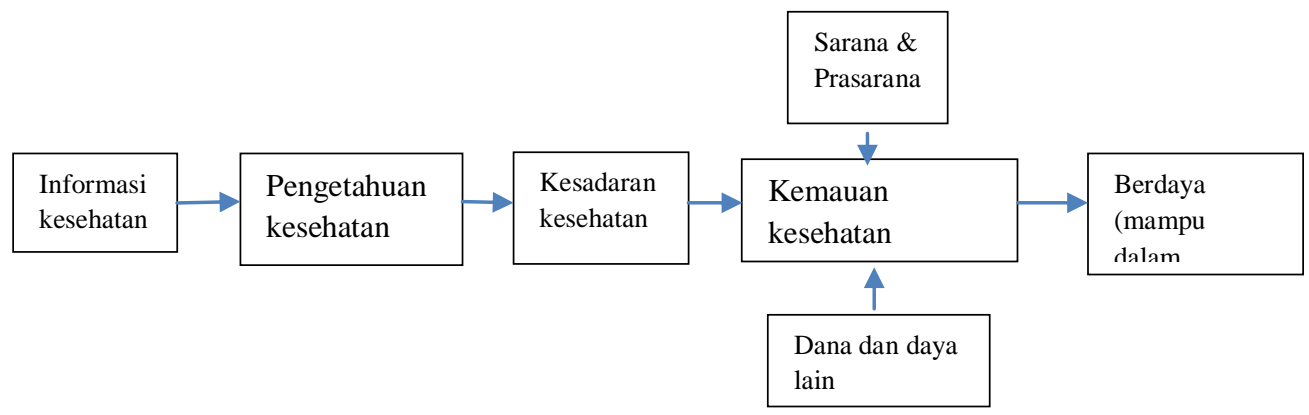

Model 1 : The Notoatmodjo Information Dissemination Model, 2007.

Community habits are corroborated by the opinion of one informant: "Community leaders are very enthusiastic about empowerment because they are role models and their requests / appeals are always heard by residents. Religious leaders play a more like Pak kyai, for example inviting mothers and children to recite the Koran, so they can insert health communication messages in the recitation material."

Wahyudi (2009) states that one of the elements of health communication is a communicator who must have credibility according to the needs of the audience. Religious leaders in Dongko Village are considered to have an understanding of communication targets as a much needed skill in health information dissemination activities. 
Health workers try to initiate residents and assist cadres through home visits (community service). Cooperating with health promotion officers from the district, Puskesmas also continues. Strategies for building an atmosphere (such as: lectures, recitation) in the respective $\mathrm{RT} / \mathrm{RW}$. PKK and posyandu cadres act as motivators who move to motivate residents in assisting community members to recover from certain diseases such as tuberculosis (TB), by reminding them of their medication schedule and routine control at the puskesmas.

Notoadmodjo mentioned that health workers are communicators of information dissemination, including: 1) facilitating the community in empowerment programs, 2) motivating the community to work together in implementing health programs, 3) transferring knowledge, skills and technology to the community so that resources can be used for independence they (Notoadmodjo, 2007).

Law Number 36 of 2009 concerning health states that Article 1 states that "health is a state of health, both physically, mentally, spiritually and socially which enables everyone to live productively socially and economically." (Law of the Republic of Indonesia Number 36 of 2000 concerning Health, 2009). So that it can be seen that the measure of health is not only on the physical, mental and social aspects but also economic and social productivity.

From the results of the FGD in Dongko Village, there are still residents who are not aware of the importance of maintaining health. This is reflected in the statement of one of the informants: "Why do you clean up, at least it will be cleaned again, dirty again." This indicates that people's knowledge and behavior regarding environmental health is still in the quite alarming category. So it is necessary to take a structural approach through the enforcement of power and policies that are intended to regulate healthy sustainability.

In health literacy activities, information management and health studies have studies on health promotion. In this case, this is done by the Trenggalek District Health Office through the Health Promotion and Kesling. In management and information and communication studies, efforts to change behavior. One of them is with literacy activities as a core part of health promotion. In this study, a method of strengthening the 
role of health information sources, including: village and school libraries and the importance of information networks, is found. Which consists of parties who are directly involved in efforts to change community behavior (such as the Village Community Empowerment Service, the Library \& Archives Service, the Health Service and the Education and Culture Office).

In the guidelines for the Implementation of Regional Health Promotion which is stated in the Decree of the Minister of Health Number 1114 / Menkes / SK / VII / 2005, it is stated that health promotion is an effort to increase the capacity of the community through learning, from, by, for, and with the community so that they can help themselves. , as well as developing community-sourced activities according to local socio-cultural conditions and supported by public policies that have a health perspective.

Furthermore, in the Law on health in Article 52 it is also explained that efforts to complete health services include promotive, preventive, curative and rehabilitative aspects. But now health services in the view of the general public are still centered on treatment and rehabilitation measures. So that it is still guided by the paradigm of illness, not a healthy paradigm. This health improvement can be pursued through health promotion activities.

Furthermore, in the Law on health in Article 52 it is also explained that efforts to complete health services include promotive, preventive, curative and rehabilitative aspects. But now health services in the view of the general public are still centered on treatment and rehabilitation measures. So that it is still guided by the paradigm of illness, not a healthy paradigm. This health improvement can be pursued through health promotion activities.

A health promotion strategy with empowerment will be more successful if it is supported by atmosphere building activities as an effort to create an environment that encourages individuals, families, and communities to prevent disease, improve health, create a healthy environment and be active in health administration efforts as stated in the Minister of Health Decree No.1114/Menkes/SK/VII/2005 concerning Guidelines for Implementation of Health Promotion in regions that: 
Health promotion is an effort to improve the ability of the community through learning, from, by, for and with the community so that they can help themselves, and develop activities that are community-based, in accordance with local socio-cultural conditions and supported by healthminded public policies.

Health literacy represents the cognitive and social skills which determine the motivation and ability of individuals to gain access to, understand and uses information in ways which promote and maintain good health. health literacy means more than being able to read promphlets and successfully make appointments. By improving people's access to health information and their capacity to use it affectively, health literacy is critical to empowerment (Nutbeam, 2006).

Health information literacy is important for the community, it needs directed community empowerment and sustainable government support. This is important for improving the quality of public health and achieving complete health, namely physically, mentally, socially, and economically. Soekijo Notoatmodjo mentioned that people who are capable or independent in the health sector, namely having good knowledge (health literacy), are as follows: (1) knowledge of diseases, both infectious and non-communicable diseases, (2) knowledge of nutrition and food that must be consumed in order to be healthy as a determining factor for one's health, (3) healthy housing and power sanitation needed to support family or community health and (4) knowledge about the dangers of smoking, and other substances that can cause health problems (Notoadmodjo, 2007).

As we all know, the success of the dissemination of health information depends on the communicator's efforts in composing messages in order to influence changes in the attitudes of the communicants. For the purpose of an independent community in the health sector as mentioned above, one of the approaches that has been taken in managing messages is related to the content of health information (messages) in the form of priority. For example, poor sanitation status is pursued by providing health education about changes in health and basic sanitation. 
The Health Office empowers community empowerment cadres (RPM), namely volunteers who care about improving the quality of surrounding health. Cadres are chosen by the community themselves, usually because they have certain skills among other things: they can read and write and are active in the community. Mubarak, said that volunteers, selected, trusted, and come from similar communities, have participated in training of cadres in the health sector as implementers, carers, and development of activities in the community in efforts to develop community health and welfare. (Mubarak\&Sayatin, 2009).

The source of the health message may be a local or government health worker, or members of the community themselves who want change. In the formulation of the strategy, it is necessary to organize messages, namely determining themes and materials.

In addition, the main requirement in influencing the audience is being able to generate attention. Communication occurs when a message is delivered and received. The message on health education is something that is considered important for people to know or do in society.

Messages can be passed from person to person in private conversations or in group meetings or health talks or in an indirect way via radio broadcasts or newspapers. As the health promoter of Puskesmas Dongko did in involving villagers to make innovations in the health sector.Promotor kesehatan sebagai bagian dari Kementrian Kesehatan yang membangun kualitas masyarakat melalui kesehatan, menyampaikan pesan dalam mengerakkan sumber daya manusia untuk sebuah proyek inovasi. Kesehatan ini akan dijadikan salah satu ujung tombak kepedulian warga terhadap kesehatan diri, keluarga dan lingkungannya.

If the audience already knows and understands the message, they tend to believe it. The results of information dissemination activities are expected to change behavior, even though behavior is too complex for a change. But facts or ideas that the public knows, understands and believes are necessary to pave the way for informed behavior change.

The communication message conveyed must be adjusted to the appropriate frame of reference and audience field of experience. Therefore, it must pay attention to: (1) the personal and physical 
condition of the audience; (2) The influence of groups and society as well as the values and norms of the existing groups and society; and (3) the situation in which the group is located.

The communication message conveyed must be adjusted to the appropriate frame of reference and audience field of experience. Therefore, it must pay attention to: (1) the personal and physical condition of the audience; (2) The influence of groups and society as well as the values and norms of the existing groups and society; and (3) the situation in which the group is located. Result interview Mr. Ari DPMD Trenggalek Secretary as: "There are changes and improvements in the development of Posyandu which originally came from the APBD to finance this. Since 2017 the governor of East Java has overhauled the regulations, now there is an increase from 172 in 2016 to 201 in 2017 posyandu".

Notoatmodjo (2007) states that health behavior can be classified into 3 groups, namely: 1) Health maintenance behavior, namely the behaviors or efforts of a person to maintain or maintain health so as not to get sick and efforts to recover when sick; 2) The behavior of seeking and using a health service system or facility, or often called health seeking behavior, is the effort or action of a person suffering from illness or an accident; 3) Environmental health behavior, namely how a person responds to the environment, both physical and socio-cultural environments and so on. So that the environment does not affect his health.

Saparinah describes the relationship between individuals and the social environment influencing each other (Notoadmodjo, 2007). Referring to the function of the Puskesmas in Decree Number 128 / Menkes / SK / 11/2004 concerning Basic Policy for Community Health Centers, including the public health center as a community empowerment center, the Puskesmas strives for individuals, especially community leaders, families and communities. Puskesmas strives for individuals, especially community leaders including the business world to have awareness, willingness, and ability to serve themselves and the community to live healthy, play an active role in fighting for health interests including financing, and participate in determining, organizing, and monitoring the implementation of health programs by taking into account the conditions and situation, especially the socio-cultural of the 
local community, the state of the recipient of the information (sociodemography) and the context of communication.

In order to expand knowledge in the health sector, community members can refer to various sources of health information. Currently, there are many posters, books, internet sites and scientific seminars that offer a variety of health information so as to obtain basic knowledge for health. As is done, health information is carried out in stages until it reaches target audiences, including: through the Whatapps (WA) social media group. The WA group members are health promoters, village midwives, and the head of the village-level PKK mobilizing team. From them, health information, both informative and persuasive, spreads to a wide audience.

In carrying out their role as facilitators, motivators and mediators, they need policy support, both in the health promotion sector at the district, sub-district and village levels, which play a major role in the implementation of community empowerment in the dissemination of health information. Likewise with non-formal leaders, such as community leaders (the oldest) and pesantren leaders who sometimes include health information in their lecture materials or advice so that citizens can improve the quality of their health, such as maintaining cleanliness as part of religious demands. Commitment to build the independence of citizens in the health sector needs to be owned by all levels who care about environmental harmony and the quality of life of its citizens. So that the communicators in the health sector are not limited to those who have authority, but it is hoped that in the future every member of the community, especially in Dongko Village, can play a role as a communicator.

Dissemination of health information in the sub-sector of community empowerment requires active participation of community members in solving their health problems. In this case, the community itself is actively thinking, planning, implementing, and evaluating health programs.

When viewed from the level of rural communities, Dongko Village is not very high. However, based on the results of observations and field interviews, generally the community members follow the 
government's health programs well in an effort to improve health quality, such as the last MR National Immunization Week (Mums and Rubella). Only one family refused to get immunization. This is due to the family's reluctance to vaccinate their children for religious reasons (containing substances that are forbidden to consume) and is stated in a stamped statement.

Community independence in the health sector as a result of empowerment in the health sector is actually a form of community responsibility so that their health rights are fulfilled. Health matters are rights to be protected and maintained by their own health, without being dependent on other parties.

\section{Conclusion}

Health actors in the village such as the village head, village community empowerment officers, village midwives and posyandu cadres are the driving force (empowerment agents). Health empowerment in conveying various health information to the people of Dongko Village. The involvement of various parties forms a gradual system so that the final subject is the community of empowering agents who are communicators of information dissemination who play their roles as facilitators, motivators, and mediators supported by community leaders, both formal and informal. In building a commitment to community independence, the community will voluntarily follow support, attention and input. Meanwhile, health workers carry out a message management strategy in the form of education and health promotion by delivering health information. For changes in health-minded behavior through outreach and counseling to village officials and community members. In addition, providing information that is persuasive in nature so that people can improve the quality of their health. Information dissemination will be successful if the communicator can analyze the audience, in this case the communicator can analyze the audience, in this case the communicator identifies based on sociodemography, health information needs and ways of selecting access to information.

The audience in the dissemination of health information has a variety of demographic aspects, needs that need to be met and different access to health. 


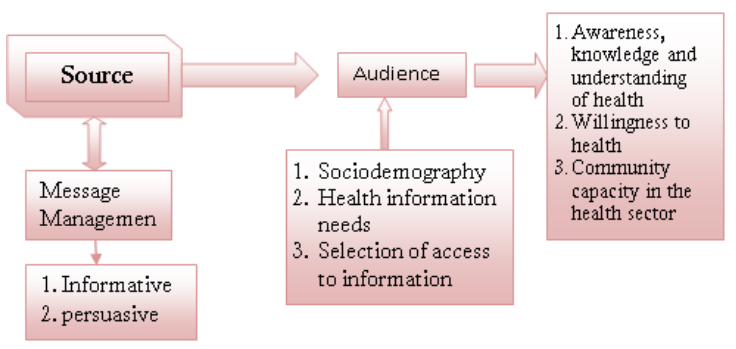

Model 2. Health Information Dissemination Model

With health promotion efforts driven by Puskesmas Dongjo and community empowerment through health literacy, it is hoped that the community can be independent in the health sector.

\section{Bibliografi}

Effendy, O.U. (2001). Ilmu, Teori dan Filsafat Komunikasi. Bandung : Citra Karya.

Hamad, I. (2007). Konstruksi Realitas Politik dalam Media. Jakarta: Granit. Irianto, K. (2014). Ilmu Kesehatan Masyarakat. Bandung: Alfabeta.

Keputusan Menteri Kesehatan No. 1114/Menkes/SK/VII/2005 tentang Pedoman Pelaksanaan Promosi Kesehatan di Daerah (2005). Indonesia.

Laksono, A.D. (2011). Analisis Profesi Penyebaran Informasi Kesehatan melalui Jejaring Sosial: Studi Kasus Pada Forum Jejaring Peduli AIDS. Buletin Penelitian Sistem Kesehatan, 14 (4). 358-365.

Liliweri, A. (2013). Dasar-Dasar Komunikasi Kesehatan. Yogyakarta: Pustaka Pelajar.

Littlejohn, S.W. (2003). Theories Of Human Communication. CA: SagePublication.

Miles \& Huberman. (1992). Analisis Data Kualitatif. Jakarta: UI Press.

Moleong, Lexy. (2006). Metodologi Penelitian Kualitatif. Bandung: Remaja Rosdakarya.

Notoadmojo, S. (2007). Promosi Kesehatan dan Ilmu Perilaku. Jakarta: Rineka Cipta.

Nutbean, D. (2006). Health Literacy as a public health goal: A challenge for contemporary health education and communication strategies into the 21 st century. Health Promotion International. 15 (3), 268. 
Rodiah, S., Rosfiantika, E, \& Yanto, A. (2016). Strategi Promosi Kesehatan Puskesmas DTP Tagarong Kabupaten Garut. Sosiohumaniora, 18 (1), 1-12.

Soekijo, N. (2007). Promosi Kesehatan dan Ilmu Perilaku. Jakarta: Rineka Cipta.

Sugiyono. (2010). Metode Penelitian Kuantitatif, Kualitatif dan R\&D. Bandung: Alfabeta.

Subqi, I. (2016).’Pola Komunikasi Keagamaan dalam Membentuk Kepribadian Anak". INJECT (Interdisciplinary Journal of Communication), 1(2), 165-180.

Undang-Undang Republik Indonesia no. 36 tahun 2009 tentang Kesehatan. Pub. 6. No. 36.

Yin, R.K. (2008). Studi Kasus: Desain dan Metode. Jakarta: Raja Grafindo Persada.

Yusup, P.M. (2018). Penggunaan Sumber-Sumber Informasi Kesehatan di Kalangan Penduduk Miskin Pedesaan dalam Komunikasi Kesehatan: Pemikiran dan Penelitian. Bandung: Remaja Rosdakarya.

Komariah, K., Perbawasar., Nugraha, A.R. (2013). Pola Komunikasi Kesehatan dalam Pelayanan dan Pemberian Informasi Mengenai Penyakit TBC pada Puskesmas di Kabupaten Bogor. Jurnal Kajian Komunikasi. 1(2). 173-185.

Mubarak, W.I. (2009). Pengaruh Kredibilitas Konselor Terhadap Sikap Remaja Mengenai HIV/AIDS di Sukabumi. Jurnal Kajian Komunikasi. 5(1). 159-167.

Niftah, Y.Z, \& Rahmat, A. (2009). Pengaruh Kredibilitas Konselor Terhadap Sikap Remaja Mengenai HIV/AIDS di Sukabumi. Jurnal Kajian Komunikasi. 5(2). 159-167.

Ratnasari, A. (2008). Komunikasi Kesehatan: Penyebaran Informasi Gaya Hidup Sehat. Mediator: Jurnal Komunikasi, 9 (1), 1-12.

Wahyudi, U. (2009). Membangun Komunikasi Kesehatan di Jawa Barat. Jurnal Observasi Komunikasi Kesehatan. Observasi Komunikasi Kesehatan, 7 (1), 1-10. 